How to cite this article:

Hardiani, H., Hastuti, D., \& Junaidi, J. (2019). An analysis of the attitudinal, contextual and gender perspectives of the entrepreneurial intentions among Indonesian millennials. Malaysian Management Journal, 23, 135-150.

\title{
AN ANALYSIS OF THE ATTITUDINAL, CONTEXTUAL AND GENDER PERSPECTIVES OF THE ENTREPRENEURIAL INTENTIONS AMONG INDONESIAN MILLENNIALS
}

\author{
HARDIANI HARDIANI * \\ DWI HASTUTI \\ JUNAIDI JUNAIDI \\ Faculty of Economics and Business \\ Universitas Jambi, Indonesia \\ *Corresponding author: hardiani@unja.ac.id
}

\begin{abstract}
The present study was designed to analyse the entrepreneurial intentions of the Indonesian millennials in Jambi City which are associated with the attitudinal, contextual and gender perspectives. This research focused on the millennial generation, namely students who will enter the labour market in the future. Data were collected from the surveys on millennials in Jambi City and analysed using the descriptive statistical tools and Structural Equation Modelling (SEM). The results indicate several factors: Firstly, the awareness level of gender equality of the millennials in the area is relatively low. There are still around a third of them who are gender-biased on the aspect of personality traits and gender roles in public sector jobs (nondomestic works). The proportion is even greater on the aspect of gender roles in domestic work. Over two-thirds of the millennials have gender-biased perceptions. Secondly, the entrepreneurial intentions of these students are relatively high. It shows that they have strong potentials to become young entrepreneurs in the future. Thirdly, the attitude and contextual factors have significant influence on the millennial entrepreneurial interests in Jambi City. The gender factor, however, does not show a significant impact as a direct influence as well as a variable moderating the influence of attitude and contextual factors.
\end{abstract}


Keywords: Entrepreneurship, perspectives, entrepreneurial intentions, millennials, Indonesia.

\section{Introduction}

Gender quality is an important issue in Indonesia, given Indonesia's low index of gender equality. According to the Global Gender Gap Report (World Economic Forum, 2018), Indonesia was ranked 85 out of 149 countries based on the gender equality index. Economic participation and opportunities are particularly low as one of the forming sub-indexes. Various efforts and policies need to be implemented to raise gender equality in Indonesia, especially in increasing the participation of women in the labour market or public sector jobs. Nevertheless, efforts to increase women's involvement in the labour market often face constraints on the limited job opportunities. The increased participation of women should therefore also coincides with an increase in the job opportunity for labour force.

The focus of the labour force in Indonesia should be shifted from job seekers to job creators in the face of global competition. Thus, fostering an entrepreneurial spirit is an alternative to increase job opportunities. The number of entrepreneurs in Indonesia, however, is only about 3.1 percent of the total population in 2019 (Akhir, 2019); while one of the requirements to become a developed country is that the proportion of entrepreneurs must be over 14 percent of the total population. Related to the gender inequality associated with low involvement of women in the labour market and the potential of entrepreneurship to increase job opportunities, it is necessary to conduct studies in order to improve gender equality based on increasing women's role in the labour market, specifically in entrepreneurship.

This study was conducted in Jambi City, the capital city of Jambi Province and the province's economic growth centre. Jambi Province has relatively low gender equality. In 2017, the Gender Empowerment Measure (GEM) of Jambi Province was placed $23^{\text {rd }}$ out of the 34 provinces in the rankings in Indonesia. In addition, the index value of 65.32 is far from the average GEM of provinces in Indonesia of 71.74 (Statistics Indonesia, 2018). GEM is an indicator that measures the active participation rate of women in economic and political activities. Based on the data, it shows that there is a high level of inequity between women and men in the labour market especially in Jambi City. 
This research was conducted among the millennial generation of Jambi City or also known as Generation Y, born between 1981 and 2000. It focused on the millennials who are students and will enter the labour market in the future. This study specifically aimed to analyse the entrepreneurship interests/intentions of the millennials in Jambi City that are associated with three factors, namely, attitude, context and gender.

\section{Literature Review}

\section{Gender Perception}

The concept of gender has fundamental differences with the concept of sex. Referring to some scholars (Handayani \& Sugiarti, 2008; Lindsey, 2015; Rokhmansyah, 2016; Saguni, 2014; William, 2006), gender is a social concept formed by the society that distinguishes functions and roles of men and women.

Community perceptions of gender will influence the way society treats men and women. In a society that has high level of gender equality awareness, roles and functions of men and women in social life will look similar. Conversely, differences in functions and roles of men and women will be evident in a society with low level of gender equality awareness. Society constructs and interprets differences between humans and produces masculine and feminine people (Puspitawati, 2012). Feminine is usually associated with soft, emotional, dependent, sensitive verbs while masculine is usually associated with courage, honesty, intelligence, with the addition of other dimensions (Shaw \& Lee, 2015). Conceptually, perception is a process of knowing and understanding the feelings of others (Baron \& Donn, 2005). Through perception, an individual realises and understands his or her own condition and surroundings (David, 1998 in Najah, 2007).

The formation of one's perception occurs through a process with different factors between individuals. Therefore, each individual will have different interpretations or perspectives on a concept or phenomenon. Pieter, Zan, Bethsaida and Saragih (2011) suggested that there are several factors that influence perception, namely: a) the interests, that is, an individual's high interest in an object/event will cause a high interest in perceiving the object/ event; b) the significance, tha is, if an individual considers an object/event to be important, it will cause him/her to be sensitive to the object/event; c) the habit, that is, the more often an individual feels the object/event, the more he or she gets accustomed to form perception; d) the constancy: an individual tends to perceive objects or events as relatively stable and unchanging, in spite of a change in shape, size, color, and brightness. 


\section{Millennial Generation/Generation Y}

Theoretically, generation is a group of individuals who have various similarities both in individual behaviour, values, and personality. These similarities are influenced and shaped by historic events and cultural phenomena that occur and are experienced at some stage in their life. The events and phenomena form collective memories that have some impact on their lives (Caspi \& Roberts, 2001; Caspi, Roberts \& Shiner, 2005; Dencker, Joshi, \& Martocchio, 2008; Noble \& Schewe, 2003; Twenge, 2000).

Based on the above theory, Howe and Strauss (2007) divided the generation into four groups, namely: a) Traditionalists, born between 1925 and 1945; b) Baby Boomers, born between 1946 and 1964; c) Generation X, born between 1965 and 1980; and d) Generation Y, born between 1981 and 2000. Among the four generations, Generation $\mathrm{Y}$ is the most prominent generation because of its diversity. This generation is also known as "Echo Boomers" or "Millennials" (Solomon, Dann, Dann \& Russell-Bennett, 2009) and is the first digital generation born in the era of digital technology. In general, Generation Y has qualified digital knowledge. They have high capability in understanding the use of new IT tools and devices (Andrea, Gabriella \& Timea, 2016; Kementerian Pemberdayaan Perempuan dan Perlindungan Aank \& Statistics Indonesia, 2018; Zloch, 2015). Among other generations, they have the highest level of education and better income level (Yolanda, 2017). In addition, Hawkins and Mothersbaugh (2010) also suggested that Generation $\mathrm{Y}$ is a generation that grew up in an era of full job opportunities for women followed by an increasing dual-income household phenomenon (i.e., both husband and wife is working), respecting ethic and cultural diversities, the widespread presence of computers and Internet, and the high level of economic uncertainty.

\section{Factors Affecting the Entrepreneurial Intentions}

Entrepreneurial desire is the initial step taken to create a business (Lee \& Wong, 2004). There are two groups of factors influencing entrepreneurship, namely, the internal factors and external factors (Priyanto, 2008). The internal factors are factors that come from within as driving forces for entrepreneurship. These factors include personal traits, attitudes, willingness, and individual abilities. The external factors come from outside the individual self. It can be from the surrounding environment, such as family, business environment, physical environment, and socio-economic environment. 
A number of studies have found various psychological characteristics that influence entrepreneurial behaviour. Those are (i) the need of achievement, (ii) initiative and creativity, (iii) the propensity to take risk, (iv) self-confidence and locus of control, (v) self-esteem and innovative behaviour, (vi) personal values and goals, and (vii) leadership (Gerry, Susana, \& Nogueira, 2008; Gorman, Hanlon \& King, 1997; Hisrich \& Peters, 1995; Huefner \& Hunt, 1991; Nishanta, 2008; Robinson, Stimpson \& Littunen, 2000).

Other studies examined the influence of attitudes of individuals on entrepreneurial interest. Based on the Theory of Planned Behaviour (TPB), the researches by Gurbuz and Aykol (2008) and Tjahjono and Ardi (2010), various attitudinal elements that affect entrepreneurial interests were revealed which include: 1) authority and autonomy; 2) the desire of having challenging tasks and high economic value work (economic opportunity); 3 ) liking creative works (self-realisation); and (4) having confidence about entrepreneurial skills (perceived confidence). It was found that perceived confidence as well as authority and autonomy are two elements of attitude that have quite strong influence on entrepreneurial interest.

\section{Methodology}

The main data were the primary data obtained from the millennial respondents in Jambi City, Jambi Province. The population in this study was all millennials (Generation Y) in the Senior High School (SMA/Sekolah Menengah Atas), Vocational High School (SMK/Sekolah Menengah Kejuruan), and University. The determination of population was carried out by considering that after completing their studies, these millennials would enter the labour market and had the potential to become young entrepreneurs. The sampling method used in this research is the stratified two-stage sampling:

1. The first stage comprised selecting the research sites; Senior High School (SMA), Vocational High School (SMK) and University as the research locations. Purposive sampling was done with the following considerations and approaches:

- There are 44 Senior High Schools, 36 Vocational High Schools, and nine universities in Jambi City. Then one Senior High School, one Vocational High School, and one University were selected; each representing the highest number of students.

- $\quad$ Based on the consideration, SMA Negeri 1, SMK Negeri 3, and Jambi University were chosen as the research locations. The two faculties in Jambi University were selected; one faculty in the social science (Faculty of Economics and Business) and the other, the natural or hard sciences (Faculty of Agriculture). 
2. The second stage involved determining samples of five percent of the target population of the research locations. Table 1 shows, based on the target population the samples were chosen randomly, using RNG (Random Number Generator) software.

Table 1

Location, Target Population, and Sample

\begin{tabular}{clcc}
\hline No & Location & Target Population & Sample \\
\hline 1 & SMA Negeri 1 & 648 & 32 \\
2 & SMK Negeri 3 & 1637 & 82 \\
3 & Fac of Economics and Business UNJA & 3242 & 162 \\
4 & Fac of Agriculture UNJA & 2156 & 105 \\
& Total & 6393 & 424 \\
\hline
\end{tabular}

Data were analysed descriptively. To examine the relationship of entrepreneurial intentions with the attitudinal, contextual, and gender perspectives, the Structural Equation Modeling (SEM) is used. The model framework is shown in Figure 1.

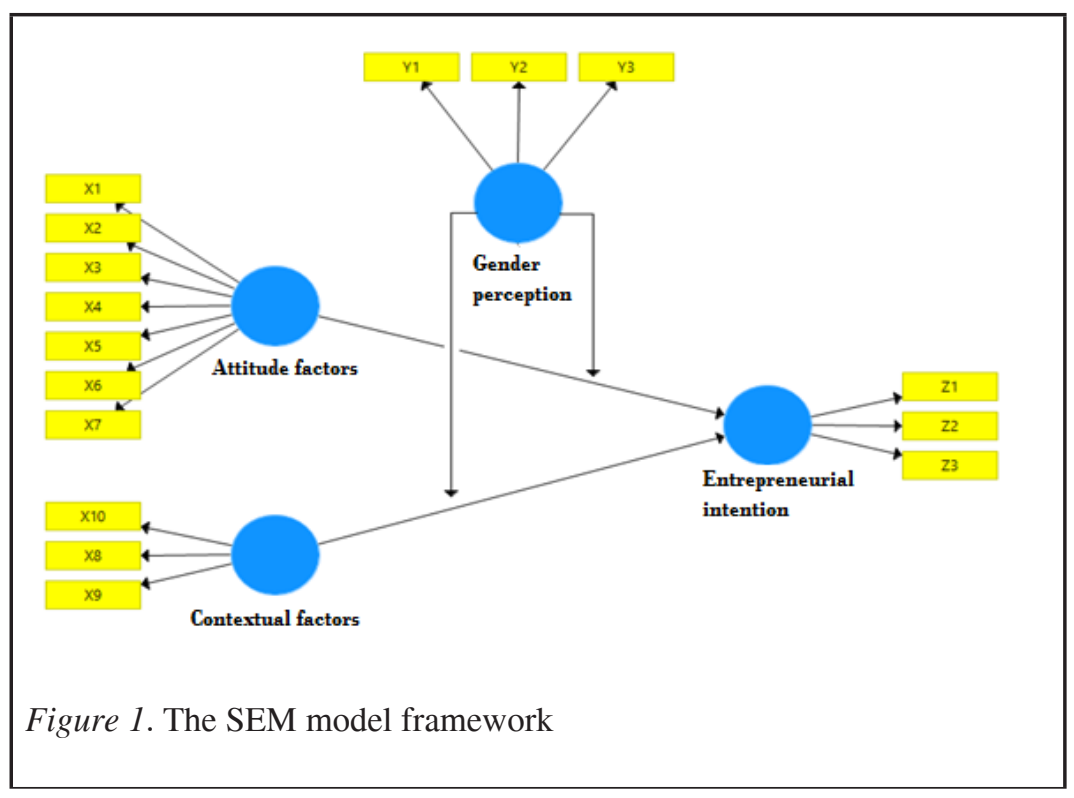

The measurement and assessment of variables and indicators in the study are given as follows: 


\section{Attitude Factors}

The measurement of individual attitudes is done using the TPB index which aims to measure a person's attitude towards entrepreneurship (Gurbuz \& Aykol, 2008). The attitude factors are measured through seven indicators with 32 statements as listed here: (i) Autonomy and authority (X1 with 6 statements), (ii) Economic challenges and opportunities (X2 with 7 statements), (iii) Security and workload (X3 with 5 statements), (iv) Avoiding responsibility (X4 with 3 statements), (v) Participation and self-realisation (X5 with 4 statements), (vi) Career and Social Environment (X6 with 4 statements), (vii) Self-confidence (X7 with 3 statements). Each statement is assessed using the Likert scale of 1 (strongly disagree) to 5 (strongly agree).

\section{Contextual Factors}

The contextual factors are measured through three indicators with 11 statements, namely: 1) The academic support (X8), using the scale of Autio et al., (2001; as cited in Gurbuz \& Aykol, 2008) consisting of four statements; 2) The social support (X9) with three statements (from scale by Gurbuz and Aykol, 2008); 3) The environmental support, using the scale by Verheul et al. (2005 as cited in Gurbuz and Aykol, 2008) consisting of four statements. Each statement is assessed using the Likert scale of 1 (strongly disagree) to 5 (strongly agree).

\section{Entrepreneurial Intention}

The entrepreneurial intention variables are measured through three indicators. Each statement is assessed on Likert scale of 1 to 5 adopted from Gerry, Susana and Nogueira (2008), namely: 1) Intention to become an entrepreneur as a career after graduation (Z1); 2) Prefer to become an entrepreneur rather than being an employee (Z2); and 3) Expect to own a business in the next one to three years $(\mathrm{Z3})$.

\section{Gender Perception}

The gender perception is measured through three indicators with the questions referring to Puspitawati's (2008) study instruments, namely: 1) Perception of personality traits (Y1), consisting of 66 questions regarding individual personality traits; 2) Perception of gender roles in domestic work (Y2), consisting of 44 questions regarding activities (works) in the family; 3) Perception of gender roles in the public sector (Y3), consisting of 68 questions regarding activities (works) in the society. The answer is given a value of 1 if the respondent chose 'only appropriate for men/only owned by 
men' or 'only appropriate for women/only owned by women'. If the answer is 'appropriate for both/owned by both', it is given a value of 2 .

\section{Results and Discussions}

\section{Gender Perception among the Millennial Generation}

The gender perception in millennial generation is analysed based on three aspects, namely perception of personality traits, perception of gender roles in domestic work, and perception of gender roles in public sector jobs. The millennials in this study are divided into two groups; the millennials who still have gender-biased perceptions, and those who don't have genderbiased perceptions. The first group is a group of individuals who still have gender-biased perceptions, while the second group is a group of individuals who no longer distinguish personality traits of men and women. The result in Table 2 show, gender perception among the millennial generation is based on the three aspects mentioned.

Table 2

Gender Perceptions of Millennials in Jambi City in 2019

\begin{tabular}{lccc}
\hline Perceptions & $\begin{array}{l}\text { Personality } \\
\text { traits }\end{array}$ & $\begin{array}{l}\text { Roles in domestic } \\
\text { work }\end{array}$ & Roles in public sector job \\
\hline Gender-biased & 39.39 & 68.87 & 31.84 \\
No longer gender-giased & 60.61 & 31.13 & 68.16 \\
Total & 100.00 & 100.00 & 100.00 \\
\hline
\end{tabular}

Source: Field survey, 2019

Referring to those three aspects, there are still around a third of the millennials (39.39\%) who are gender-biased (with a score of 66-98) related to personality traits. Based on perceptions of gender roles in domestic work, the majority $(68.87 \%)$ of millennials are gender-biased (with a score of 38-57).

Furthermore, based on perceptions of gender roles in public sector work, there were 31.84 percent of millennials who have gender-biased perceptions (with a score of 102-153). This millennial generation gender perception is in line with several other studies which revealed that the cultural beliefs and traditions still remain as obstacles for women to to engage in public sector work (Aliyu, 2013; Aiswarya \& Ramasundaram, 2013). 


\section{The Millennials' Attitude towards Entrepreneurship}

As shown in Table 3, the attitude of millennials towards entrepreneurship is relatively good. This can be seen from the scores of all indicators that are above 3.00. Indicator with the highest average score is participation and selfrealisation, while indicator with the lowest average score is responsibility.

Table 3

Scores of the Millennials' Attitude towards Entrepreneurship in Jambi City in 2019

\begin{tabular}{llc}
\hline No & Statements & Average Score \\
\hline 1 & Autonomy and authority & 3.91 \\
2 & Economic challenges and opportunities & 4.05 \\
3 & Security and workload & 3.95 \\
4 & Responsibility & 3.18 \\
5 & Participation and self-realization & 4.06 \\
6 & Career and social environment & 3.91 \\
7 & Self-confidence & 3.87 \\
\hline
\end{tabular}

Source: Field survey, 2019

Entrepreneurial attitude is one of the factors influencing entrepreneurial intentions. Attitude is considered as the most important in the micro entrepreneurship (Robbins \& Judge, 2016). Azwar (2016) explained that attitude is an evaluative response, either positive or negative. In this sense, attitude includes preferences or likes or dislikes toward something as an object. In other words, the good attitude of millennial generation on entrepreneurship is expected to foster entrepreneurial intentions among the generation.

\section{Contextual Factors of the Millennial Generation for Entrepreneurship}

Table 4 shows that the contextual factors of millennials for entrepreneurship are relatively good. This can be seen from the scores of all indicators that are above 3.00. Indicator with the highest score is academic support, while indicator with the lowest average score is the environmental support. 
Furthermore, based on the indicators, the highest average score is academic support, followed by the social support and environmental support. The high score of academic support is obtained because it is affected in spite of the fact that the millennial generation right now is those who are still in school. The same result is also found in the previous study by Hasanah and Hasanah and Nurhasikin (2019). They examined the millennials in the State Polytechnic of Batam, Indonesia.

\section{Table 4}

Scores of Contextual Factors of Millennials for Entrepreneurship in Jambi City, 2019

\begin{tabular}{lll}
\hline No & Statements & Average score \\
\hline 1 & Academic support & 3.73 \\
2 & Social support & 3.68 \\
3 & Support of the environment & 3.29 \\
\hline
\end{tabular}

Source: Field survey, 2019

\section{The Entrepreneurial Intentions of the Millennial Generation}

Based on Table 5, the three indicators of the entrepreneurial intentions show relatively the same score, between 3.70 and 3.80 . Referring to the averages score of 3.77 (on a scale of 1-5), the entrepreneurial intention score of the millennials is observed to be relatively high.

Table 5

Scores of the Entrepreneurial Intention of the Millennial Generation in Jambi City, 2019

\begin{tabular}{llc}
\hline No & Statements & $\begin{array}{l}\text { Average } \\
\text { score }\end{array}$ \\
\hline 1 & $\begin{array}{l}\text { Intend to become an entrepreneur as a career after } \\
\text { graduation }\end{array}$ & 3.80 \\
2 & Prefer to become an entrepreneur rather than an employee & 3.80 \\
3 & Expect to own business in the next 1-3 years & 3.70 \\
\hline & Average & 3.77 \\
\hline
\end{tabular}

Table 5 shows that there is a high potential of millennials to become young entrepreneurs in the future. The high entrepeneurial intention score in this 
millennial generation was also found by Indriyani and Margunani (2018). This finding is also supported by the study by Pratana and Margunani (2019) which indicated that over two thirds $(67.53 \%)$ of students has high entrepreneurial intentions.

\section{The Influence of Attitudinal, Contextual and Gender Perspectives on the Entrepreneurial Intention}

Before conducting the analysis, an evaluation of the model was carried out first, which was related to the validity and reliability of the indicators on its latent (construct) variables. Validity test uses convergent test and discriminant validity of the indicators. Reliability test uses two criteria, namely, the composite reliability and Cronbach's alpha.

Based on the testing of the initial model, it was found that one indicator of attitude (X4), one indicator of contextual (X10), and two indicators of gender perceptions (Y1 and Y2) were not valid and reliable. These four indicators are then excluded from the model. On the other hand, all indicators on entrepreneurial intention variables meet the requirements of validity and reliability. After removing the invalid and unreliable indicators, a modified model is constructed as shown in Figure 2.

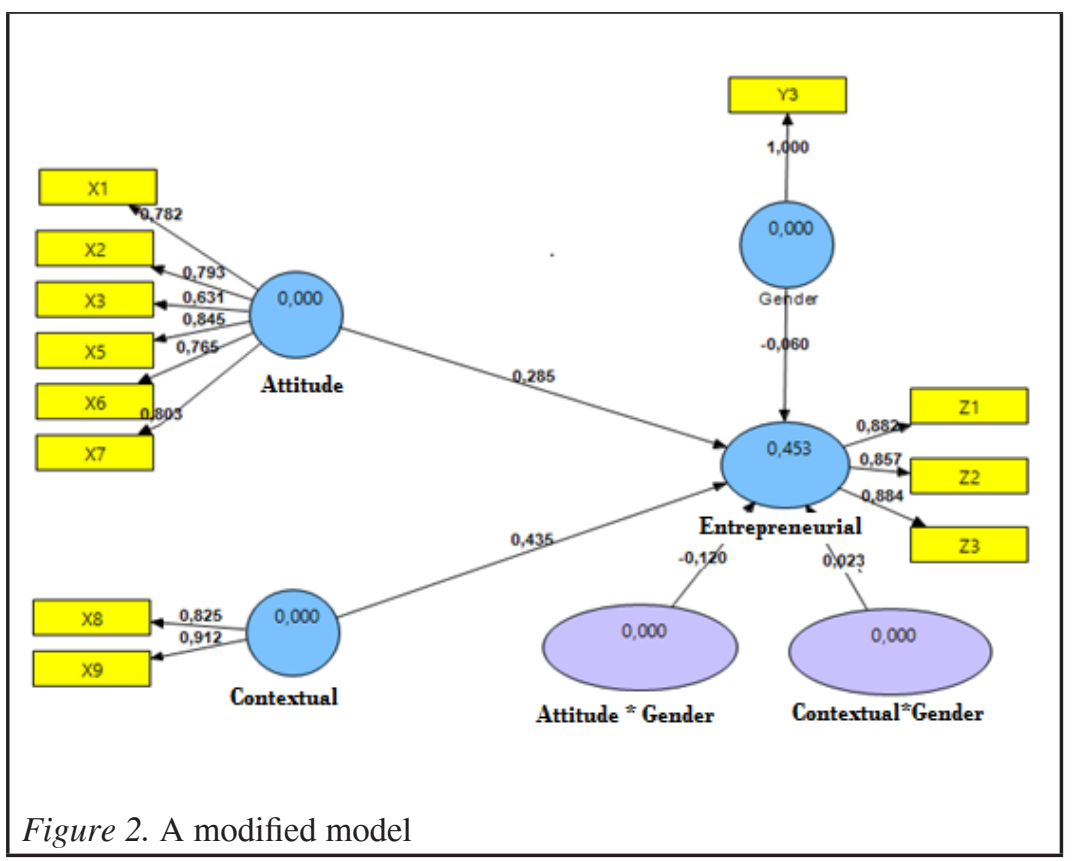


Based on Figure 2, it can be seen that the correlation (loading factor) of all construct indicators is above 0.5. Similarly, this appeared in discriminant validity test (Table 6). The average variance extracted (AVE) value for each construct shows greater than the correlation value between the construct and other constructs in the model. Table 6 also shows that all variables have composite reliability value above 0.60 . In other words, the model has good reliability.

Table 6

Correlation between Construct, AVE, Cronbach's alpha, and Composite Reliability of Modified Model

\begin{tabular}{|c|c|c|c|c|c|c|c|c|}
\hline & \multicolumn{6}{|c|}{ Correlation } & \multirow[b]{2}{*}{$\begin{array}{l}\text { Cronbach's } \\
\text { Alpha }\end{array}$} & \multirow[b]{2}{*}{$\begin{array}{l}\text { Composite } \\
\text { Reliability }\end{array}$} \\
\hline & Gender & $\begin{array}{l}\text { Entrepre- } \\
\text { neurship }\end{array}$ & Contextual & Attitude & $\begin{array}{l}\text { Attitude* } \\
\text { Gender }\end{array}$ & $\begin{array}{l}\text { Contextual* } \\
\text { Gender }\end{array}$ & & \\
\hline Gender & 1.000 & & & & & & 1.000 & 1.000 \\
\hline $\begin{array}{l}\text { Entrepre- } \\
\text { neurship }\end{array}$ & -0.031 & 1.000 & & & & & 0.846 & 0.907 \\
\hline Contextual & 0.026 & 0.629 & 1.000 & & & & 0,684 & 0.861 \\
\hline Attitude & -0.015 & 0.586 & 0.688 & 1,000 & & & 0.867 & 0.898 \\
\hline $\begin{array}{l}\text { Attitude* } \\
\text { Gender }\end{array}$ & -0.182 & -0.100 & 0.004 & -0.013 & 1.000 & & 0.867 & 0.854 \\
\hline $\begin{array}{l}\text { Contextual } \\
* \text { Gender }\end{array}$ & -0.017 & -0.042 & 0.001 & -0.028 & 0.485 & 1.000 & 0.707 & 0.801 \\
\hline AVE & 0.466 & 0.764 & 0.524 & 0.521 & 0.548 & 0.541 & & \\
\hline
\end{tabular}

The influence between variables is shown through coefficient and significance of $t$ statistic as shown in Table 7 .

Based on Table 7, both attitude and contextual factors have significant effects on entrepreneurial intention of millennials at a significance level of one percent. This result is in line with the previous studies (Aloulou, 2016; Aprilianty, 2012; Ardiyani \& Kusuma, 2016; Kurniawan, Khafid \& Pujiati, 2016; Soria-Barreto, Honores-Marin, Gutierrez-Zepeda \& GutierrezRodriguez, 2017; Trivedi, 2016; Wijaya, Nurhadi \& Kuncoro, 2015).

However, gender perception does not show a significant effect, either a direct influence or as a variable moderating attitude variables and contextual variables on the entrepreneurial intention. In other words, although about one third of the millennials have gender-biased perceptions of the personality traits and roles in the public sector jobs and over two thirds have genderbiased perceptions of the domestic work, it does not affect the entrepreneurial interest of millennials. 
Table 7

The Modified Model Hypothesis Testing

\begin{tabular}{|c|c|c|c|c|c|}
\hline & $\begin{array}{l}\text { Original } \\
\text { Sample } \\
\text { (O) }\end{array}$ & $\begin{array}{l}\text { Sample } \\
\text { Mean } \\
\text { (M) }\end{array}$ & $\begin{array}{l}\text { Standard } \\
\text { Deviation } \\
\text { (STDEV) }\end{array}$ & $\begin{array}{l}t \text { statistics } \\
(\mid \mathrm{O} / \\
\text { STDEV|) }\end{array}$ & $\begin{array}{l}p \\
\text { values }\end{array}$ \\
\hline Gender -> Entrepreneurship & -0.0601 & -0.0492 & 0.0833 & 0.7223 & 0.114 \\
\hline $\begin{array}{l}\text { Contextual -> } \\
\text { Entrepreneurship }\end{array}$ & 0.4349 & 0.4271 & 0.1075 & 4.0468 & 0.000 \\
\hline $\begin{array}{l}\text { Contextual*Gender -> } \\
\text { Entrepreneurship }\end{array}$ & 0.0227 & -0.0232 & 0.1158 & 0.1964 & 0.724 \\
\hline Attitude $->$ Entrepreneurship & 0.2850 & 0.2933 & 0.1050 & 2.7132 & 0.000 \\
\hline $\begin{array}{l}\text { Attitude*Gender -> } \\
\text { Entrepreneurship }\end{array}$ & -0.1201 & -0.0047 & 0.1660 & 0.7235 & 0.397 \\
\hline
\end{tabular}

Note: * denotes significance at $1 \%$ level

\section{Conclusion and Recommendations}

The gender perception of millennials in Jambi City is relatively low. There are still one third of millennials who are gender-biased on the aspects of personality traits and gender roles in public sector jobs. The proportion is even greater on the gender roles in domestic work. More than two-thirds of the millennials in Jambi City have gender-biased perceptions.

The entrepreneurial intention of millennials in Jambi City is relatively high. This shows that there is a high potential of millennials who will become young entrepreneurs in the future. Attitudinal and contextual factors have significant effects on the entrepreneurial intention of millennials in Jambi City. However, gender perception does not show a significant effect, either as a direct influence or as a variable moderating the influence of attitude and contextual factors.

The gender equality perception in millennials in Jambi City is relatively low. Therefore, it is necessary to increase efforts to promote gender equality, especially in younger generation, through formal and informal educational institutions. High entrepreneurial interest of millennials should be followed by skills in entrepreneurship. Therefore, the government should be able to increase the number of entrepreneurship training among young people. 


\section{References}

Aiswarya, B., \& Ramasundaram, G. (2013). Indian women in technology: An empirical analysis of role conflict. Malaysian Management Journal, 17, 13-26

Akhir, J. (2019). Syarat jadi negara maju: Jumlah pengusaha 14 peratus dari rasio penduduk. Retrieved from https://economy.okezone.com/ $\mathrm{read} / 2019 / 04 / 09 / 320 / 2040896 /$

Andrea, B., Gabriella, H .C., \& Timea, J. (2016). Y and Z generations at workplaces. Journal of Competitiveness, 8(3), 90-106.

Aliyu, S. M. (2013). An assesment of women enterpreneurship performance in Nigeria. Malaysian Management Journal, 17, 1- 12.

Aloulou, W. J. (2016). Predicting entrepreneurial intentions of final year Saudi University business students by applying the theory of planned behavior. Journal of Small Business and Enterprise Development, 23(4), 1142-1164.

Aprilianty, E. (2012). Pengaruh kepribadian wirausaha, pengetahuan kewirausahaan dan lingkungan terhadap minat berwirausaha siswa SMK. Jurnal Pendidikan Vokasi, 2(3), 311-324.

Ardiyani, N. P. P., \& Kusuma, A. K. (2016). Pengaruh sikap, pendidikan dan lingkungan keluarga terhadap minat berwirausaha. Jurnal Manajemen Unud, 5(8), 5155-5183.

Azwar, S. (2016). Sikap manusia: Teori dan pengukurannya (2nd ed.). Yogyakarta: Pustaka Pelajar.

Baron, R. A., \& Donn, B. (2005). Psikologi sosial. Jakarta: Erlangga.

Caspi, A., \& Roberts, B. W. (2001). Personality development across the life course: The argument for change and continuity. Psychological Inquiry, 12(2), 49-66.

Caspi, A., Roberts, B. W., \& Shiner, R. L. (2005). Personality development: Stability and change. Annual Review of Psychology, 56, 453-484.

Dencker, J. C., Joshi, A., \& Martocchio, J. J. (2008). Towards a theoretical framework linking generational memories to workplace attitudes and behaviors. Human Resource Management Review, 18(3), 180-187.

Gerry. C, Susana. C., \& Nogueira. F. (2008). Tracking student entrepreneurial potential: Personal attributes and the propensity for business start-ups after graduation in a portuguese university. International Research Journal Problems and Perspectives in Management, 6(4), 45-53.

Gurbuz, G., \& Aykol, S. (2008). Entrepreneurial Intentions of young educated public in Turkey. Journal of Global Strategic Management, 4(1), 47-56.

Gorman, G., Hanlon, D., \& King, W. (1997). Some research perspectives on entrepreneurship education, enterprise education and education for small business management: A ten - year literature review. International Small Business Journal, 15(3), 56-77.

Hasanah, A., \& Nurhasikin. (2019). Analisis faktor yang berpengaruh terhadap niat berwirausaha mahasiswa. Jurnal of Business Administration, 3(2), 194-204. 
Hawkins, D. I., \& Mothersbaugh, D. L. (2010). Consumer behavior: Building marketing strategy (11th ed.). Irvin: McGraw-Hill.

Handayani, T., \& Sugiarti, (2008). Konsep dan teknik penelitian gender. Malang: UMM Press.

Hisrich, R. D., \& Peters, M. P. (1995). Entrepreneurship: starting, developing and managing a new enterprises (3rd ed.). New York: McGraw-Hill.

Howe, N., \& Strauss, W. (2007). The next 20 years: How customer and workforce attitudes will envolve. Harvard Business Review, JulyAugust 2007, 41-52.

Indriyani, L., \& Margunani. (2018). Pengaruh kepribadian, pendidikan kewirausahaan, dan lingkungan keluarga terhadap minat berwirausaha. Economic Education Analysis Journal, 7(3), 848-862.

Kariyawan, B. (2015). Meminimalisir stereotip antar gender dengan menggunakan teknik ungkap tangkap curahan hati pada materi diferensiasi sosial di SMA Cendana Pekanbaru. Jurnal Perempuan, Agama dan Gender, 14(1), 38-54.

Kementerian Pemberdayaan Perempuan dan Perlindungan Anak \& Badan Pusat Statistik. (2018). Profil Generasi Milenial Indonesia. Jakarta: Kementerian Pemberdayaan Perempuan dan Perlindungan Anak.

Kurniawan, A., Khafid, M., \& Pujiati, A. (2016). Pengaruh lingkungan keluarga, motivasi, dan kepribadian terhadap minat wirausaha melalui self efficacy. Journal Economic Education, 1(1), 100-109.

Lee, S. H., \& Wong, P. K. (2004). An exploratory study of technopreneurial intentions: A Career anchor perspective. Journal of Business Venturing, 19(1), 7-28.

Lindsey, L. L. (2015). Gender roles: A sociological perspective. New York: Routledge.

Littunen, H. (2000). Entrepreneurship and the Charac- teristics of the Entrepreneurial Personality. International Journal of Entrepreneurial Behaviour and Research, 6(6), 295-309.

Najah, A. (2007). Hubungan antara persepsi anak terhadap pola asuh orang tua dengan motivasi belajar (Unpublished Master Thesis). Universitas Muhammadiyah Surakarta. Surakarta, Indonesia.

Nishanta, B. (2008). Influence of personality traits and socio-demographic background of undergraduate students on motivation for entrepreneurial career: The case of Srilanka. Paper presented at the EAMSA Conference, Japan.

Noble, S. M., \& Schewe, C. D. (2003). Cohort segmentation: An exploration of its validity. Journal of Business Research, 56(12), 979-987.

Pieter, Zan, H., Bethsaida, J., \& Saragih, N. Mh. (2011). Pengantar psikopatologi untuk keperawatan. Jakarta: Kencana.

Pratana, N. K., \& Margunani. (2019). Pengaruh sikap berwirausaha, norma subjektif dan pendidikan kewirausahaan terhadap intensi berwirausaha. Economic Education Analysis, 8(2), 533-550.

Priyanto, S. H. (2008). Di dalam Jiwa ada Jiwa: The backbone and the social construction of entrepreneurships. Paper presented at Professor inaugural speech Universitas Kristen Satya Wacana. Salatiga, Indonesia 
Puspitawati, H. (2012). Gender dan keluarga konsep dan realitas di Indonesia. Bogor: IPB Press.

Robinson, P. B., Stimpson, D. V., Huefner, J. C., \& Hunt, H. K. (1991). An attitude approach to the prediction of entrepreneurship. Entrepreneurship Theory and Practice, 15(4), 13-31.

Robbins, S. P., \& Judge, T. A. (2016). Perilaku organsasi. Jakarta: Salemba Empat.

Rokhmansyah, A. (2016). Pengantar gender dan feminisme: Pemahaman awal kritik sastra feminisme. Yogyakarta: Garudhawaca.

Saguni, F. (2014). Pemberian stereotype gender. Jurnal Musawa, 6(2), 195224.

Shaw S. M., \& Lee, J. (2015). Women's voices feminist visions: Classic and contemporary readings. New York: McGraw-Hill Education.

Solomon, M. R., Dann, S., Dann, S., \& Russell-Bennett, R. (2007). Consumer behaviour: Buying, having, being. Frenchs Forest, New South Wales: Pearson Education.

Soria-Barreto, K., Honores-Marin, G., Gutierrez-Zepeda, P., \& GutierrezRodriguez, J. (2017). Prior exposure and educational environment towards entrepreneurial intention. Journal of Technology Management and Innovation, 12(2), 45-58.

Statistics Indonesia. (2018). Analisis gender provinsi Jambi 2017. Jambi: Statistics Indonesia

Tjahjono, H. K., \& Ardi, H. (2008). Kajian niat mahasiswa manajemen Universitas Muham- madiyah Yogyakarta untuk menjadi wirausaha. Utilitas Jurnal Manajemen dan Bisnis, 16(1), 46-63.

Trivedi, R. (2016). Does university play significant role in shaping entrepreneurial intention? A cross-country comparative analysis. Journal of Small Business and Enterprise Development, 23(3), 790-811.

Twenge, J.M. (2000). The age of anxiety? The birth cohort change in anxiety and neuroticism, 1952-1993. Journal of Personality and Social Psychology, 79(6), 1007-1021.

World Economic Forum (WEF). (2018). The global gender report 2018. World Economic Forum: Geneva Switzerland.

William, de Vries Dede. (2006.) Gender bukan tabu: Catatan perjalanan fasilitasi kelompok perempuan di Jambi. CIFOR: Bogor.

Wijaya, T., Nurhadi, \& Kuncoro, A. M. (2015). Intensi berwirausaha mahasiswa: Perspektif pengambilan risiko. Jurnal Siasat Bisnis, 19(2), 109-123.

Yolanda, N. (2017). Analisis faktor-faktor yang mempengaruhi perilaku belanja konsumen pada produk Apparel di Tunjungan Plaza Surabaya (Unpublished Master's Thesis). Universitas Katolik Widya Mandala. Surabaya, Indonesia.

Zloch, D. (2015). The perception of the millennial generation and their engagement in climate change activism (Unpublished Master's Thesis). Lund University, Lund, Sweden. 